\title{
Role Identities and Pro-environmental Behavior among Farmers
}

\author{
Jordan Burke' \\ Department of Sociology, Washington State University \\ Washington, United States \\ Katrina Running \\ Department of Sociology, Social Work, and Criminology, \\ Idaho State University \\ Idaho, United States
}

\section{Abstract}

In this exploratory work, we investigate the relationship between the role identity "farmer" and farmers' land management practices using data from 30 semistructured interviews with farmers in southeastern Idaho. Guided by social identity principles, we examine how farmers' collective identity influences environmental attitudes and behaviors. Overall, we find that most farmers have implemented some conservation practices on their land, particularly those related to soil and water, and see themselves and other farmers as good environmental stewards. However, we also find that many of their chosen conservation practices required little to no sacrifice, and in addition to benefiting the environment, were also cost-minimizing business decisions. We find that as a group, these farmers' beliefs, attitudes, and behaviors are largely focused on productive efficiency. We argue that this focus often puts them in competition with other social groups, which ultimately reinforces group saliency and adversely affects relations between farmers and other groups seeking to influence farming practices.

Keywords: conservation, farming, group conflict, pro-environmental behavior, role identities, social identity theory

\section{Introduction}

Farmers are one of the most important stakeholder groups when it comes to using and affecting natural resources. Over the past 50 years, worldwide agricultural production has approximately tripled (United Nations [UN], 2016). Globally, $40 \%$ of total land and $70 \%$ of fresh water is used for agricultural purposes

1 Corresponding author: jmfisher@wsu.edu. 
(Kleinschmidt, 2009). In Idaho, as of the last agricultural census in 2012, about 22\% of all available land was classified as farmland, and in the three primary counties in southeastern Idaho-Bingham, Power, and Bannock counties-there is more land in agriculture than in industry (Southeast Idaho Council of Governments, 2013; United States Department of Agriculture [USDA], 2015).

Farmers use natural resources like land and water to grow their crops, and these activities are associated with adverse impacts, including deforestation and water pollution from agricultural run-off (McGuire et al., 2013; UN, 2016). Synthetic fertilizer use has been associated with high levels of nitrate in groundwater, which leads to hypoxia in aquatic ecosystems and contamination of drinking water sources (Nolan et al., 2002). Pesticide use has also contributed to declining biodiversity due to habitat loss and degradation, particularly among natural pollinators such as the monarch butterfly (National Academy of Sciences, 2007). With respect to effects on air and climate, agricultural activities account for $17.4 \%$ of greenhouse gas emissions (Kleinschmidt, 2009). It is estimated that by $2050,70 \%$ more food production will be required to sustain the population, further exacerbating these already significant environmental impacts (UN, 2016).

Farming has substantial social, cultural, and economic importance in Idaho, and historically, Idaho was essentially established by agriculture. With the expansion of the railroad in the mid-19th century, settlers moved in to southeastern Idaho because of the fertile land found in the Snake River Valley (Arrington, 1994). The number of settlers increased even faster after the Desert Land Act of 1894, which provided federal funding for dam projects and hence expanded the opportunity for irrigation. In fact, it was not until the 1960s that more people resided in "urban"2 as opposed to "rural" areas, and it was not until 1962 that Idaho had a US Census Bureau Standard Metropolitan Statistical Area (Arrington, 1994). Currently, Idaho ranks as the 39th state in terms of population, but due to climate conditions in primarily Southern Idaho and the importance of agriculture, ranks second nationwide in irrigation withdrawals (United States Geological Survey, 2016). Agriculture is also a central part of the local culture, from rural school districts releasing students for a week or two to work harvest in the fall to an entire museum devoted to the potato. More recently, agribusiness was identified as the third largest industry in Idaho, accounting for about $31 \%$ of total employment and over 100,000 jobs (Idaho Department of Labor, 2014).

Given the prevalence of agriculture in Idaho, and the environmental concessions that often accompany large-scale agricultural activities, it is important for projections of both economic productivity and natural resource sustainability/environmental stewardship to analyze how farmers weigh trade-offs between the two. Fortunately,

2 For the purposes of this discussion, we define "urban" as a place having 2,500 or more inhabitants (USDA Economic Research Service, 2019). 
considerable research has begun to address these questions. For example, Pilgeram (2011) found that increases in familial income and educational attainment improve the likelihood that one will engage in more sustainable farming practices. Similarly, Cary and Wilkinson (1997) found that profitability was the largest contributor to conservation-oriented behavior among farmers. Others have found that the expense of implementing and maintaining conservation was a major concern, as well as the perceived effectiveness of these efforts (Porter et al., 2007; Tosakana et al., 2010). This suggests that the cost of conservation efforts is a barrier if farmers believe the methods are more expensive and not particularly effective.

Other studies have identified farming subsidies as a major factor affecting conservation behavior (Aughney \& Gormally, 2002; Herzon \& Mikk, 2007). In a study of agro-environmental schemes in Europe, however, Burton et al. (2008) found that although such incentives result in farming conservation practices, they have done little to change environmental attitudes. Rather, research has found farmers who engage in conservation practices are often intrinsically motivated because of land or place attachment, the emotional connection between person and place (Ryan et al., 2003), connectedness to nature, defined as the "extent to which an individual feels that he or she is a part of nature" (Gosling \& Williams, 2010, p. 298), and/or community norms (Cutforth et al., 2001) rather than an overall pro-environmental orientation.

Here, we define pro-environmental behavior as farmers' land management practices that promote natural resource sustainability in the long term and minimize environmental impact. Prior research has concluded that people who live in rural areas are often more directly affected by their environment than those in urban settings, and therefore experience more targeted environment-related concerns, such as fear of wildfires due to unmanaged forests or loss of resource-based employment (Hamilton et al., 2013; Dunlap, 2010; Molnar, 2010). Research has also found that respondents in rural counties prefer conserving natural resources for the future instead of using them to stimulate more rapid economic development where unemployment is low, revealing a preference for long-term sustainability over short-term growth, when feasible (Hamilton et al., 2010). However, other studies have found that perceived profitability is the most important factor influencing farmers' decision to adopt conservation practices (Cary \& Wilkinson, 1997), and that conservation programs that are too rigid and prohibit farmers from using their hard-won skills are often unpopular (Burton et al., 2008). In this research, we seek to further explore how the formation and dynamics of the social identity "farmer" impacts farmers' self-reported environment-related attitudes and behaviors through analyzing interviews with 30 farmers in southeastern Idaho. In particular, we seek to answer the question: How do farmers' role identities as producers of food for a growing population affect their willingness to engage in environmental stewardship and conservation activities? 
We begin by reviewing the literature on social identity theory, with an emphasis on role identity and group competition, and the saliency of the farmer identity for people who farm for a living. We then outline our data collection and analysis procedures, including how we recruited participants for our study and the basic demographics defining who we ultimately interviewed, along with how we coded our data and why. We then discuss our overall findings, including how intergroup competition and role responsibility affect farmers' environmental behaviors and land management decisions. We conclude with some thoughts for how the findings from this exploratory work may be used by state natural resource managers to encourage farmers to adopt mutually beneficial environmentally sustainable practices.

\section{Theoretical foundation}

\section{The self and behavior}

Social identity theory (SIT) posits that one's identity is strongly linked with the group in which one belongs (Turner et al., 1987). As such, group members are more likely to adopt in-group norms rather than norms associated with out-groups (Tajfel, 1982), though to varying degrees depending upon the strength of one's affiliation with a group (McDonald et al., 2012). Past studies have used social identity principles to help explain farmers' environment-related behavior (De Weerd \& Klandermans, 1999; Fielding et al., 2008; Groth et al., 2016), as well as people's behavior more generally (Bartels \& Onwezen, 2014; Dono et al., 2010). Groth et al. (2016) found that both full-time and part-time farmers in the United States allied with the farmer identity, and De Weerd and Klandermans (1999) found that individual affiliation with farmers as a social group was a good predictor of participatory political action, illustrating the influence of the farmer identity on behavior. Using a combination of the theory of planned behavior and SIT, Fielding et al. (2008) found that in-group dynamics (i.e., group saliency) and in-group/out-group relations affected farmers' decisions to engage in riparian zone conservation practices.

Generally, identity theorists focus on individuals' role identities, which are "the meanings individuals attach to themselves as an occupant of a role in the social structure" (Stets \& Biga, 2003, p. 403). In this study, we focus specifically on farmers' role identity and how their role as both producers and land managers affects their environment-related behavior. One of the most salient aspects of how one's individual identity is related to role identity and in-group/out-group relations is how one develops a sense of purpose. In general, people sharing a social identity are more likely to share a sense of purpose, especially when this purpose comes into competition with the purpose of out-group members. Tajfel (1982) argues that in a competitive group situation, especially when this competition is centered on issues of "power, rank, prestige," or "access to resources," in-group attitudes and behaviors 
become increasingly unified, while sentiments toward the out-group become increasingly "undifferentiated" and socially stereotyped (p. 13). In this study, we focus specifically on farmers' role identity, and how their shared goal of feeding a growing global population interacts with other goals related to their role identities when considering land management choices with environmental consequences.

\section{The farmer identity}

One's social identity is related to the role expectations of the social group in which one belongs. These expectations are situated within and shaped by broader structural and contextual influences. For example, farmers represent a specific role within both global food production as a professional activity and in the rural communities in which they live. Stenholm and Hytti (2014) argue that this role of farmer is socially constructed based on social norms and farmers' experience with institutions, resulting in two distinct professional social identities: the producer and the entrepreneur. The producer identity emphasizes profit as a means to legitimacy. The entrepreneur identity promotes competition between farmers in an attempt to become "the biggest and the best" (Stenholm \& Hytti, 2014, p. 133). Similarly, McGuire et al. (2013) argue that the "good farmer identity" in American culture is reliant on one's ability to maximize production. This production-oriented good farmer identity emerged from government incentive programs that rewarded increases in agricultural production. According to Burton (2004), this emphasis on "production-oriented roles came to symbolise, both to farmers and to the country, the notion of good farming practice and enabled farmers to claim a high social position as caretakers of the nation's food supply" (p. 195). This is most apparent when looking at current farming practices and structure compared with the past. The majority of farms today are large-scale industrial operations, even for the 97\% that are still deemed "family farms" (Leonard, 2014). They are growing larger and producing more, while smaller farms are disappearing due to their inability to compete (Leonard, 2014). Most of this shift can be attributed to the purchasing of midsize farm land by larger farming operations. For instance, in 1987, midsize farms accounted for $47 \%$ of all cropland. By 2012, this figure dropped to $29 \%$, while large farms increased by $21 \%$ during this same time period (MacDonald \& Hoppe, 2017). This creates a competitive environment, one where failure to advance and grow often results in the loss of one's heritage. Meanwhile, other social groups are advocating environmental policies that would further limit farmers' ability to expand.

According to Tajfel and Turner (1979), when groups are in competition with each other, the result may be heightened bias in favor of one's in-group. In the case of farmers, we expect to find that one's affiliation with the farming group will affect their relationship with other groups, especially those deemed a threat to productive capacity. Farming activities may come into conflict with neighboring residents due 
to urban encroachment. Urban settlements are in ever-closer proximity to farms, resulting in conflicts between farmers and neighbors, often stemming from concerns related to farming practices, such as chemical spraying, dust, odors, and noise, as well as those introduced by urban encroachment, such as littering, vandalism, and trespassing (Hammond et al., 2010). Other conflicts arise from the use of genetically modified or genetically engineered crops, which certain individuals and various environmental and public health groups oppose (Gerasimova, 2016). Farming also requires, and often compromises, the quantity and quality of natural resources, which results in conflict between farmers and other social groups, such as environmental groups and regulatory agencies (Henle et al., 2008). Therefore, group conflict with groups that seek to regulate environmental behaviors may prove to be one of the most important factors related to these farmers' environmental attitudes, broadly defined as feelings, beliefs, or opinions about the environment, and their subsequent pro-environmental behavior. Conversely, conservation efforts that align with this identity, such as those that provide incentives to improve water efficiency or prevent soil erosion, may better align with this production-oriented identity, making their adoption more attainable. These are practices that also improve such things as agricultural run-off, which may also decrease public concerns about certain aspects of agricultural production, hence decreasing conflict between farmers and other social groups. Here we seek to shed light on how farmers as a social group perceive other competing groups, and whether the farming identity is related to farmers' willingness to engage in behavior to improve the environment. Given the structure of large-scale agricultural production and farmers' role within this structure, we anticipate that there are barriers to adopting certain conservation practices. We also anticipate, however, that other practices which improve productive efficiency will be more readily adopted by farmers.

\section{Data and methods}

Our data for this study consist of 30 semi-structured in-depth interviews conducted as part of the Managing Idaho's Landscapes for Ecosystem Services (MILES) Idaho's Farmers Research Project. We collected the sample using conveniencesampling methods, recruiting participants by distributing flyers in local businesses or community hang-outs where we knew farmers spent time, as well as by identifying farmers listed as members of farming associations online, or through personal contacts and calling them to ask if they would be willing to be interviewed. The majority of the farmers we contacted agreed to participate, even those we cold-called based on phone numbers found on the internet, and we conducted the interviews from June to August 2015. In order to meet our criteria for inclusion in the study, we confirmed that each farmer we interviewed farmed at least 100 acres and was the sole or partial owner and decision-maker on the farm they managed. Our geographic area of interest was within an approximately 100-mile radius to 
Pocatello, Idaho, which was one of the three state sites defined by the MILES project. We chose to interview 30 farmers in order to achieve saturation in responses, which was sufficient within our analysis, which was likely given the homogeneity of both our sample and land management practices in the area. Our interview protocol included themes related to the impact that farming activities may have on natural resources (or ecosystem services), farmers' observations of environmental change on their land and their level of climate concern, and farmers' participation in conservation programs, as per the MILES project's main research objectives, among a few other more general questions. Each interview was conducted by one or two members of the research team, which consisted of one faculty member, one graduate student, and two undergraduate research assistants. We then transcribed and analyzed the recorded interviews, which ranged from approximately 30 minutes to two hours in length.

In looking at demographic characteristics, all of the respondents in the sample we compiled were male and white, which is representative of farmers in the area as most farms were established in the first part of the 20th century when opportunities for land ownership favored white men. Locally, the culture is still quite religious and conservative; 25 of the 30 respondents identified as politically conservative, while the other 5 self-identified as an independent/moderate, and though we did not ask explicitly about religious affiliation, most of our respondents mentioned attending church or their belief in God. The median age of respondents was 55 years, ranging from 27 to 78 years of age. The median household size was two persons, ranging from one to eight. All of the respondents had knowledge of the day-to-day operations of their farms, with all but two having direct ownership (these two were children of the owners). The respondents represented a broad range of farm sizes, from 110 to 25,000 acres, with a mean of 3,618 and a median of 1,600 acres. The majority of respondents (28) relied either entirely or mostly on irrigation practices to successfully grow their crops. The two that were able to dry farm were from a particular area that receives more precipitation and farmed crops, such as wheat, which are more amenable to dry farming than many other more water-intensive crops in the region, such as potatoes or sugar beets. The majority of respondents were born into farming (26), while only four reported being first-generation farmers. Again, this is typical of the area, as land prices currently make it prohibitively expensive to start a competitive farm from scratch, especially since the state of Idaho stopped issuing new irrigation permits in the early 1990s. The main crops grown were wheat, potatoes, sugar beets, alfalfa, corn, and hay, which is typical of southeastern Idaho.

With respect to our data analysis process, we began with a fairly open coding plan by having each member of the research team read through the interviews and note important themes related to environmental observations, attitudes, and behaviors. We then went back through the data with specific coding categories in mind, based on our original research questions when embarking upon the project, 
such as farmers' perceptions of environmental change, levels of climate concern, environment-related behavior, and perceived threat from other groups. One of the themes we began noticing in relation to environment-related behavior was the manner in which the respondents discussed their role in food production, and in particular how often they brought up their perceived responsibility to produce food for the global population almost as an excuse or justification for choosing not to implement certain conservation practices on their land. This theme emerged from responses to various questions about participation in environmental sustainability initiatives. It also became evident through analysis that the farmers perceived the responsibilities of their role to be in direct conflict with the objectives of other groups, namely environmentalists and regulatory agencies. We have analyzed the data in the first two categories mentioned above in previously published research (Running et al., 2017). In this paper, we focus on the latter two categories listed, including how farmers' role as farmers affects their environment-related behavior and what happens when this role puts them in conflict with other groups' priorities.

\section{Results and discussion}

\section{Environmental behavior among farmers}

Almost all of the farmers we interviewed had implemented conservation efforts on their farms, particularly those related to soil and water. These efforts could be categorized as conservation-oriented behavior, though farmers explained their motivation for doing so in terms of business advantage, since one has to have good soil and a sufficient amount of water in order to grow a crop. Dale, a 63-year-old wheat, sugar beet, potato, and sweet corn farmer ${ }^{3}$ put it this way:

Everything we do, we have to sustain this land. Everything we do is trying to keep the highest productivity, the healthiest land that we can keep in order to produce for the next year, for the next generation, for those who will come along.

Later on in his interview, Dale also emphasized his stewardship toward his land again, explaining:

We feel like we are good stewards of the soil. We've planted wind breaks. I've planted probably 5,000 trees in my lifetime. Not that all of them lived, but the majority of them have. So, we are trying to do things that will help save the ground.

3 All names are pseudonyms to protect the identity of the respondents. 
Similarly, Greg, a 58-year-old wheat, potato, and alfalfa farmer described his land stewardship choices and his decision to participate in one conservation-related program this way:

We took advantage of some government programs to change from flood irrigation to sprinkler irrigation, cause it's more efficient use of water. But, so sprinkler systems and all those are conservation measures according to the government. Whether those were wise ones or not, I don't know. Some of the things we do is we don't plow anymore. That helps with soil erosion so that you don't have any clean fields.

Another theme that frequently came up when we asked each farmer whether they had adopted any conservation measures was an intentional caution in regard to chemical use. Many of the farmers we spoke to were concerned about the effects of chemical pesticides and fertilizers, though this concern often seemed to center on their ability to sell and profit from their crops and regulatory uncertainty rather than their overall environmental impact. Baldwin, a 67-year-old hay and feed grain farmer remarked:

Yeah I'm a little concerned, of course you don't know what's going on the corporate world as far as fertilizer and chemicals, and everything else. And the environmental, EPA and everything is going to try and change or make things harder to grow crops.

These guys that want to farm all the time, they want to stay in business, and they don't want to jeopardize their farm. If they put the wrong chemical on their ground, there is a chance they won't be able to get a potato crop on the same ground next year because they put the wrong chemical on their wheat to kill the weeds or something.

A few farmers also revealed genuine concern for the health of people and other life when discussing their chemical use, as well. Robert, a 64-year-old wheat, potato, sugar beet, alfalfa, and safflower farmer told us he had changed chemical practices in order to reduce harm to bees. Another farmer had strong feelings about farmers' responsibilities toward their communities when applying chemicals on their fields. Zack, a 65-year-old alfalfa farmer described what he considered best practice regarding chemical application this way:

Sometimes they put this acid on the grain stubble, and sometimes I think you are smart to get in your car and drive away. Quite a few of these chemicals they put on the fields these days besides the acid, they will post and say do not enter because there's a hazardous product out there for 24 hours or 36 hours. The only one comment I would make is that some of these farmers that put on the acid, I think they should have to come and tell the people within say a one or two-mile radius the day before and say we're spraying this field with acid tomorrow and we want you to know that. 
Other farmers, however, were more concerned about outside groups taking away the chemicals they needed to keep their crops free of pests. Allan, a 58-year-old barley, wheat and potato farmer told us:

You know, I am worried about continued availability of fertilizers; which can allow us to push our yields. I am worried about making sure that we do have chemicals if we end up with pests that we cannot control any other way. That we have not cut ourselves so tight with regulations that nobody continues to try to make something to deal with funguses and insects and whatever else might be out there trying to stop us from growing a good crop.

Similarly, Evan, a 62-year-old wheat, barley, alfalfa, and mustard farmer expressed frustration that regulatory bodies were taking away chemicals he considered effective, particularly in controlling bugs, in order to protect the overall environment. He said:

The thing I do notice, and we don't really know, is the bugs. I don't know why. I tell everybody it's cause DDT finally wore off. But they have taken a lot of the chemicals away from us that worked on these bugs, ones that live in the ground, the wire worm, those type of things. We have got to control them; because they can devastate a crop. I've had them take $40 \%$ of a wheat field.

Thus, though some of the farmers recognized the risk of chemical exposure, and expressed a preference for transparent application and responsible use, when regulations interfered with their ability to keep their crops bug-free, farmers typically resented the power of out-group regulators to curb their access to effective products.

\section{Farmers and intergroup competition}

Twenty-six of the 30 participants grew up on a farm, which is typical of farmers in southeastern Idaho. In the course of our interviews, we noted how strongly our respondents identified as farmers, and how often it came up. For example, our respondents generally spoke in terms of the collective (i.e., farmers, us, we, etc.), when discussing farming-related activities. This did not appear to differ depending on whether one was born into a farming family or not, though our sample does not provide much diversity in this area (only four farmers were not born into a farming family). Another clue that highlighted how important farming was to our respondents was how many of them told us it was important that their land remain in agriculture after they retired; 21 had specific plans to sell or pass on their farm to family members. 
In general, social scientists have found that strength of association with a social group is an important factor in explaining behavior, especially behavior that promotes that group's interests when it comes into competition with the interests of another group (Tajfel \& Turner, 1979). This behavior is thought to exist on a continuum, with one extreme emphasizing no group influence and the other exhibiting almost total group influence on behavior, with two major factors determining where on the continuum a behavior may lie: the amount of competition and stratification between competing groups that exists. In the case of farmers as a group, we found that they occupy a very salient and distinctive place within their communities, often due to their familial and historical ties. This also relates to the prominence of the identity. This is summed up well by Lane, a 52-year-old potato and sugar beet farmer:

I think it's a way of life, and I think family farms provide community with good people that love the community and that love the environment.

Again, however, this strong identification can also lead to a great deal of perceived stratification between their social group and others, as well as perceived group competition. With respect to group competition, most of our respondents communicated that regulatory agencies/government were a concern, and constrained their ability to farm successfully. This theme emerged from various questions throughout the interviews. For example, our respondents often mentioned constraining forces in regard to climate change legislation and/or environmentalists. When discussing emission regulations on his farming equipment, Eddy, a 55-yearold wheat and hay grower, remarked:

Their exhaust will have to be cleaner than the air they are taking in. Which all sounds really good and everything, but it tripled the cost of an engine in a tractor. So those regulations all sound real good and it's good to have the air cleaned up; but nobody ever analyzes the cost of what we are doing.

Ian, a 61-year-old wheat, potato, and sugar beet farmer, also expressed frustration with environmental regulations, and explicitly brought up both some of the tradeoffs between food production and limiting environmental impact, as well as concerns about economic competition with less regulated countries. Ian explained:

You know, I do think—and I sound like a guy that hates regulations—but I see documentaries where India and China haven't taken steps to regulate the output of huge factories, rubber factories and that, and it's a mess. So, I think there's a place for regulation. I just think that we need to be middle of the road somewhere. I think Al Gore would just stop production of food and would have us all going back to doing it by hand and if we did that, it would be really the safe way to go, but people would die of starvation. 
In this case, $\mathrm{Al} \mathrm{Gore}{ }^{4}$ and the climate change activists were being portrayed as a direct threat to farmers' noble efforts to feed the world. Others brought up frustration with environmentalists and their competing interests in regards to water regulation. In response to a question about the environmental changes he had noticed and where his competition for necessary resources were coming from, Ben, a 78-year-old tree farmer, commented:

Some of it is coming from having to send more water down the river for the salmon. Some years we really need it bad; but the environmentalists have got it bottled up to where we gotta give it to the salmon.

Throughout our interviews, these concerns about expenses imposed due to regulations and worry about long-term water availability were mentioned frequently, often in the context of competition with other interests, including environmentalists' objections to chemical application and GMO (genetically modified organism) technology, and warnings about how these barriers could adversely affect food production. In these instances, farmers often painted an "us versus them" mentality, with the "them" portrayed as well-meaning but silly city folks without intimate knowledge of the natural environment. Wayne, a 40-year-old wheat, potato, sugar beet, and hay farmer explained his frustration with these "out-groups" this way:

\begin{abstract}
because it's very scary when different environmental groups and different government agencies want to come out and tell you what's wrong or what's right when it's not even their area of expertise. It's very scary. I worry a lot about our water rights. I worry about a lot of the rules and regulations that they pass, and at the end of the day, they're all a joke because there's no one to enforce them. If they'll let the farmers be farmers, and the pencil pushers be pencil pushers, everyone will just get along just fine. But, there's just a lot of things that you know, they talk about soils, they've never gone out. They've never even kneeled down on their hands and took a handful of soil. They've grown tomatoes that they got at Costco. It's ridiculous. Nobody cares about the dirt like the guy making a living off the dirt.
\end{abstract}

The fact is, farming is a volatile industry. Farms in southeastern Idaho are becoming fewer and larger because owners of larger farms are purchasing many of the smaller farms (USDA, 2015). Farmers' profit margins are becoming increasingly squeezed, they must quickly adapt to the whims of the global marketplace, and they are being forced to become more efficient in order to stay competitive (Dimitiri et al., 2005). These shared obstacles seem to strengthen farmers' identification with each other, though, which was illustrated by our respondents talking with sympathy about the challenges their fellow farmers faced. But these challenges also may contribute to their shared dislike and distrust for regulatory oversight related to a number of issues such as chemical oversight and exclusion, environmental standards, and

$4 \mathrm{Al}$ Gore is a former United States Vice President and Congressman who is a climate change educator, author and activist, as well as the joint recipient of the 2007 Nobel Peace Prize (NobelPrize.org, 2019). 
conservation practices. Farmers seemed to blame these other social groups for the regulatory oversight that they view as stemming from the irrational worries of those with little knowledge of the demands involved in growing a crop.

\section{Farmers' role in food production}

Beyond what was discussed when we asked respondents about how they made decisions about applying pesticides and fertilizers, or participating in conservation programs, mentions of their duty to feed the world often came up in reference to new seed technology. Farmers frequently lamented how divorced average consumers are from the act of growing food, including the environmental benefits of genetically engineered seeds which both increase efficiency and reduce the need for chemical inputs. In discussing GMO technology for agriculture, Eddy, a 55-year-old wheat and hay farmer, told us:

I think if we take them away, the poorest people in the world are the ones that are going to suffer. Because of lack of supplies, they will be the last people to be able to buy and eat. It is easy for us to get on our high horse and say we're not going to have any when we know we are going to be fed and not be concerned about people in the world that won't be.

Oliver, a 59-year-old barley farmer, expressed a similar sentiment:

You know I'm actually in favor of genetically modified crops, just because they predict by the year 2050 there will be 9-plus billion people in the world, and there's going to be starvation if we don't, if the farmers can't raise the food. And God's not making any more farm land ... as you know there's becoming less and less farm land all the time with urban encroachment and things, so the remaining and existing farmers have to increase more and more food in order to feed a growing population.

The point these farmers seemed to be highlighting is that farmers serve an important function in society. We all need food, and farmers provide that food, and their work is even more important in a time where the value of farms is increasing and the number of farms is diminishing. Nationwide, the number of farms worth over USD500,000 increased from 1,300 to 2,000 between 2004 and 2013, while the total number of farms decreased by 500 in the same time period (USDA National Agricultural Statistics Service Northwest Regional Field Office, 2014). This trend suggests that power over the food supply is being distilled down to an increasingly smaller group, which SIT would predict is likely to increase the saliency of group norms among farmers resulting in more cohesion (Tajfel \& Turner, 1979). Forsyth and Danisiewicz (1985) also point out that professions the public recognizes as "essential," "exclusive," and "complex" are particularly powerful as a group (p. 65). Farms are most certainly essential and complex, and as farms decrease in number, farmers are becoming scarcer. Farmers did seem to be aware of these shifts, and one 
of the points they made in defending their societal usefulness in the face of these declines was by emphasizing their valuable role in keeping food production stable and food prices affordable. Eddy lamented:

I wish they would do more to preserve the small farms. I think that is a resource we are sorely going to miss. I think that we are setting up for a famine. If you have a small number of farmers and times get really tough and they can't make it go, I think it's going to make a huge impact on our food supply. Whereas, if you had a lot of farmers and some of them had struggles they'd help each other out and find ways of getting by.

In addition, Greg conveyed to us his perspective on the service farmers perform for American consumers:

As farmers, I think we have kept food cheap in this country, comparatively. I mean you can complain all you want about, oh my gosh I can't believe how much grapes are [etc.]. But overall, we still get to use the majority of our money on other things besides food.

Thus, in addition to strongly identifying as farmers, it seems clear that these farmers are also highly aware of the much-needed role they occupy in food production. This may then help explain why they become so frustrated when perceiving threats to their ability to produce. Dale described his objection to the public's emotion-based rejection of genetically modified potatoes this way:

We tried some GMO potatoes back in the 1990s. They are very good. The only reason why they got taken off the market is because of the emotional thing that they did in Europe. Nothing was based on science. That technology was a great technology.

Previous efforts that look at responses to identity threats assert that individuals tend to address these threats through a process of normalization and/or invalidation (Bernett \& Breakwell, 2001; Halpern-Flescher et al., 2001; Lima et al., 2005). In utilizing these processes, farmers emphasize the positive effects of their own land management practices while ignoring or invalidating activities or beliefs that may inhibit production and hence threaten both their identities as farmers and their ability to run a profitable farming business. Ultimately, identity theory predicts that individuals with strong social identities will respond negatively to any activity that threatens their group's goals (McDonald et al., 2012; Tajfel 1982). This then helps explain why farmers, with their strong identity as such, see groups like regulatory agencies or environmentalists as competing with their interests and threatening their productivity and credibility. This also suggests that members of these groups who seek to encourage different behaviors among farmers would be better served by recognizing and showing appreciation for farmers' expert knowledge of their land, their sincere care for its long-term health, and the service they provide the rest of us by producing food. 


\section{Conclusion}

Using data from 30 semi-structured interviews with farmers in southeastern Idaho, we analyzed how farmers' role identities influence their environment-related attitudes and behaviors. We used social identity principles to understand how and why people who identify as farmers are sometimes hostile to regulatory agencies and/ or environmental groups, even though in many cases their overall environmental values are quite similar. Ultimately, we found that farmers' antagonism toward these groups is likely the result of perceived competition and threats to productivity, as well as a general sense of being labeled as negligent environmental stewards, despite a strong commitment to their land's health being central to their own identity as farmers.

The farmers we interviewed expressed the belief that other social groups constrain their ability to execute their role as food provider. Current economic dynamics such as changes in farm size and the dwindling number of farmers likely contribute to this perception. It also aligns with Tajfel and Turner's (1979) explanation that group conflict stems from "antagonism between dominant and subordinate groups," based on the unequal distribution of resources, particularly when concerns of self-esteem or worth are also at play (p. 38). In a society where agriculture has become the focus of much environmental research and scrutiny, it may be difficult for farmers to trust people who do not farm for a living for a number of reasons. For one, people in these groups are often trying to control natural resources that farmers need to grow their crops, especially as populations grow and demand for scarce resources increase. Additionally, through this control, these groups may infringe on farmers' ability to inexpensively and efficiently produce their commodities. Finally, this competition puts farmers' identities at risk through the possibility of losing access to the natural resources they need, and thus their productive capacity. This ultimately results in farmers feeling unfairly maligned as negligent environmental stewards, even though they are the ones outside, with their fingers on the pulse of their land, as they strive to provide for out-of-touch urban people who think food comes from grocery stores and that preserving salmon habitat is more important than preserving multigenerational farms.

We base these conclusions on the fact that most farmers we talked to do engage in conservation efforts. They also talk about their land with respect and gratitude and express concern about long-term land and resource sustainability. Additionally, they speak sincerely about loving their jobs because they provide a chance to work outside and know their local environmental intimately, in this way exhibiting positive sentiments about the environment. 
Although our sampling methodology and analysis do not lend to generalizable findings, this exploratory work should provide insights to guide future research efforts examining farmers' environment-related behavior and their participation in conservation programs. Future studies should further evaluate the causes and consequences of intergroup conflict with environmental groups and regulatory agencies, as well as with other stakeholder groups such as industries and suburban developers. Many of the farmers we interviewed expressed extreme distrust toward these groups, which suggests future efforts-especially those that require voluntary cooperation—should prioritize building trust between farmers and government agencies before expecting positive outcomes. One approach for doing this may be to explicitly incorporate farmers' input within the regulatory process. This will likely require more collaboration and contact between farmers and government or conservation-oriented groups (which takes time), ideally underpinned by mutual respect for each other's personal as well as collective goals. But our findings reveal that farmers sincerely care about their land, and also empathize with other farmers and generally are committed to being good neighbors and citizens in their rural communities. As such, we believe there is much potential for government regulators, environmentalists, and farmers to work together to overcome intergroup conflict and promote and implement sustainable land management practices in the coming years.

\section{References}

Arrington, L. J. (1994). History of Idaho. Moscow, ID: University of Idaho Press.

Aughney, T. \& Gormally, M. (2002). The nature conservation of lowland farm habitats on REPS and non-REPS farms in County Galway and the use of traditional farm methods for habitat farm management under the rural environmental protection scheme. Irish Journal of Agri-Environmental Research, 2, 1-14.

Bartels, J. \& Onwezen, M. C. (2014). Consumers' willingness to buy products with environmental and ethical claims: The roles of social representations and social identity. International Journal of Consumer Studies, 38, 82-89. doi.org/10.1111/ijcs.12067.

Bernett, J. \& Breakwell, G. M. (2001). Risk perception and experience: Hazard personality profiles and individual difference. Risk Analysis 21(1), 171-177. doi.org/10.1111/02724332.211099 .

Burton, R. J. F. (2004). Seeing through the "good farmer's" eyes: Towards developing an understanding of the social symbolic value of "productivist" behaviour. Sociologia Ruralis, 44, 195-215. doi.org/10.1111/j.1467-9523.2004.00270.x.

Burton, R. J. F., Kuczera, C., \& Schwarz, G. (2008). Exploring farmers' cultural resistance to voluntary agri-environmental schemes. Sociologia Ruralis, 48(1), 16-37. doi.org/10.1111/ j.1467-9523.2008.00452.x. 
Cary, J. W. \& Wilkinson, R. L. (1997). Perceived profitability and farmers' conservation behavior. Journal of Agricultural Economics, 48(1), 13-21. doi.org/10.1111/j.14779552.1997.tb01127.x.

Cutforth, L. B., Francis, C. A., Lynne, G. D., Mortensen, D. A., \& Eskridge, K. M. (2001). Factors affecting farmers' crop diversity decisions: An integrated approach. American Journal of Alternative Agriculture, 16(4), 168-176. doi.org/10.1017/s088 9189300009164.

De Weerd, M. \& Klandermans, B. (1999). Group identification and political protest: Farmers' protest in the Netherlands. European Journal of Social Psychology, 29, 10731095. doi.org/10.1002/(sici)1099-0992(199912)29:8<1073::aid-ejsp986>3.0.co;2-k.

Dimitiri, C., Effland, A., \& Conklin, N. (June 2005). The 20th century transformation of US agriculture and farm policy (Economic information bulletin number 3 ). Washington, DC: Economic Research Service/USDA.

Dono, J., Webb, J., \& Richardson, B. (2010). The relationship between environmental activism, pro-environmental behavior and social identity. Journal of Environmental Psychology, 30, 178-186. doi.org/10.1016/j.jenvp.2009.11.006.

Dunlap, R. E. (2010). Climate change and rural sociology: Broadening the research agenda. Rural Sociology, 75(1), 17-27. doi.org/10.1111/j.1549-0831.2009.00010.x.

Fielding, K. S., Terry, D. J., Masser, B. M., \& Hogg, M. A. (2008). Integrating social identity theory and the theory of planned behavior to explain decisions to engage in sustainable agricultural practices. British Journal of Social Psychology, 47, 23-48. doi.org/ $10.1348 / 014466607 \times 206792$.

Forsyth, P. B. \& Danisiewicz, T. J. (1985). Toward a theory of professionalization. Work and Occupations, 12(1), 59-76. doi.org/10.1177/0730888485012001004.

Gerasimova, K. (2016). Debates on genetically modified crops in the context of sustainable development. Science and Engineering Ethics, 22, 525-547. doi.org/10.1007/s11948015-9656-y.

Gosling, E. \& Williams, K. J. H. (2010). Connectedness to nature, place attachment and conservation behavior: Testing connectedness theory among farmers. Journal of Environmental Psychology, 30, 298-304. doi.org/10.1016/j.jenvp.2010.01.005.

Groth, T. M., Curtis, A., Toman, E., \& Mendham, E. (2016). The utility of a collective identity construct to explore the influence of farming identity on natural resource management. Society and Natural Resources, 29(5), 588-602. doi.org/10.1080/089419 20.2015.1095376.

Halpern-Flescher, B., Millstein, S., Ellen, J., Adler, N., Tshann, J., \& Biehl, M. (2001). The role of behavioural experience in judging risk. Health Psychology, 20, 120-126. doi.org/10.1037//0278-6133.20.2.120. 
Hamilton, L. C., Colocousis, C. R., \& Duncan, C. M. (2010). Place effects on environmental views. Rural Sociology ,75(2), 326-347. doi.org/10.1111/j.1549-0831.2010.00013.x.

Hamilton, L. C., Hartter, J., Safford, T. G., \& Stevens, F. R. (2013). Rural environmental concern: Effects of position, partisan, and place. Rural Sociology, 79(2), 257-281. doi.org/ 10.1111/ruso. 12023 .

Hammond, S. V., Norton, M. V., Schmidt, E. E., \& Sokolow, A. (2010). California communities deal with conflict and adjustment at the urban-agricultural edge. California Agriculture, 64(3), 121-128. doi.org/10.3733/ca.v064n03p121.

Henle, K., Alard, D., Clitherow, J., Cobb, P., Firbank, L., Kull, T., McCracken, R. F.A., Moritz, N., Rebane, M., Wascher, D., Watt, A., \& Young, J. (2008). Identifying and managing the conflicts between agriculture and biodiversity conservation in Europe-A review. Agriculture, Ecosystems and Environment, 124, 60-71. doi.org/10.1016/j.agee. 2007.09.005.

Herzon, I. \& Mikk, M. (2007). Farmers' perceptions of biodiversity and their willingness to enhance it through agri-environmental schemes: A comparative study from Estonia and Finland. Journal for Nature Conservation, 15(1), 10-25. doi.org/10.1016/j.jnc. 2006.08.001.

Idaho Department of Labor. (2014, January). Idaho's agricultural employment maintains growth despite recession. Idaho Employment.. Retrieved from labor.idaho.gov/publications/ $\mathrm{lmi} /$ pubs/idempnews/archived/iecurJan14.pdf.

Kleinschmit, J. (2009). Agriculture and climate: The critical connection. Minneapolis: Institute for Agriculture and Trade Policy.

Leonard, E. (2014). Middle ground: Uniting city, farm, and nature with diverse agroecosystems. American Journal of Economics and Sociology, 73(5), 1007-1134. doi.org/ 10.1111/ajes.12083_2.

Lima, M. L., Barnett, J., \& Vala, J. (2005). Risk perception and technological development at a societal level. Risk Analysis, 25(2), 1229-1239. doi.org/10.1111/j.1539-6924. 2005.00664.x.

MacDonald, J. M., \& Hoppe. R.A. (2017). U.S. cropland is consolidating into larger farms. Retrieved from www.ers.usda.gov/amber-waves/2017/december/us-cropland-isconsolidating-into-larger-farms/.

McDonald, R. I., Fielding, K. S., \& Louis, W. R. (2012). Conflicting norms highlight the need for action. Environmental Behavior, 46, 139-162. doi.org/10.1177/0013916512453992.

McGuire, J., Morton, L. W., \& Cast, A. D. (2013). Reconstructing the good farmer identity: Shifts in farmer identities and management practices to improve water quality. Agriculture and Human Values, 30(1), 57-69. doi.org/10.1007/s10460-012-9381-y.

Molnar, J. J. (2010). Climate change and societal response: Livelihoods, communities, and the environment. Rural Sociology, 75(1), 1-16. doi.org/10.1111/j.1549-0831.2010.00011.x. 
National Academy of Sciences. (2007). Status of pollinators in North America. Washington DC: The National Academies.

Nobelprize.org (June 2019). Al Gore biographical. Retrieved from www.nobelprize/org/ prizes/peace/2007/biographical.

Nolan, B. T., Hitt, K. J., \& Ruddy, B. C. (2002). Probability of nitrate contamination of recently recharged groundwaters in the conterminous United States. Environmental Science \& Technology, 36(10), 2138-2145. doi.org/10.1021/es0113854.

Pilgeram, R. (2011). "The only thing that isn't sustainable ... is the farmer": Social sustainability and the politics of class among Pacific Northwest farmers engaged in sustainable farming. Rural Sociology, 76(3), 375-393. doi.org/10.1111/j.15490831.2011.00051.x.

Porter, N. B., Tucker, D. I., Leviston, Z., Russell, S. N., Po, M., Fry, A. J., McIntyre, W., Nancarrow, B. E., \& Bates, L. E. (2007). Partnerships and understanding towards targeted implementation: Identifying factors influencing land management practices. Perth, Australia: CSIRO Land and Water.

Running, K., Burke, J., \& Shipley, K. (2017). Perceptions of environmental change and climate concern among Idaho's farmers. Society and Natural Resources, 30(6), 659-673. doi.org/10.1080/08941920.2016.1239151.

Ryan, R. L., Erickson, D. L., \& De Young, R. (2003). Farmers' motivations for adopting conservation practices along riparian zones in a Midwestern agricultural watershed. Journal of Environmental Planning and Management, 46, 19-37. doi.org/10.1080/713676702.

Southeast Idaho Council of Governments. (2013, April 20). Region V: Comprehensive economic development strategy. Retrieved from www.nado.org/wp-content/uploads/ 2014/08/ID-Southeast-Idaho-Council-of-Governments-2013.pdf.

Stenholm, P. \& Hytti, U. (2014). In search of legitimacy under institutional pressures: A case study of producer and entrepreneur farmer identities. Journal of Rural Studies, 35, 133-142. doi.org/10.1016/j.jrurstud.2014.05.001.

Stets, J. E. \& Biga, C. F. (2003). Bringing identity theory into environmental sociology. Sociological Theory, 21(4), 398-423. doi.org/10.1046/j.1467-9558.2003.00196.x.

Tajfel, H. (1982). Social psychology of intergroup relations. Annual Review Psychology, 33, $1-39$.

Tajfel, H. \& Turner, J. (1979). An integrative theory of intergroup conflict. In W.G. Austin \& S. Worchel (Eds.), The social psychology of intergroup relations (pp. 33-47). Monterey, CA: Brooks/Cole.

Tosakana, N. S. P., Van Tassell, L. W., Wulfhorst, J. D., Boll, J., Mahler, R., Brooks, E. S., $\&$ Kane, S. (2010). Determinants of the adoption of conservation practices by farmers in the Northwest wheat and range region. Journal of Soil and Water Conservation, 65(6), 404-412. doi.org/10.2489/jswc.65.6.404. 
Turner, J. C., Hogg, M. A., Oaks, P. J., Reicher, S. D., \& Wetherell, M. W. (1987). Rediscovering the social group: A self-categorization theory. New York, NY: Blackwell.

United Nations (UN). (2016). International decade for action "Water for Life" 2005-2015. UN Water. Retrieved from www.un.org/waterforlifedecade/food_security.shtml.

United States Department of Agriculture (USDA). (2015). State fact sheet. Retrieved from www.ers.usda.gov/data-products/state-fact-sheets/state-data.aspx?StateFIPS=16\&State Name=Idaho\#.U-5XxfldXzg.

United States Geological Survey. (2016). Which states irrigated the most? Retrieved from water.usgs.gov/edu/qa-usage-stateirr.html.

USDA Economic Research Service. (2019). What is rural? Retrieved from www.ers.usda. gov/topics/rural-economy-population/rural-classifications/what-is-rural.aspx.

USDA National Agricultural Statistics Service Northwest Regional Field Office. (2014). 2014 Idaho annual agriculture bulletin. Boise, ID: United States Department of Agriculture. 
This text is taken from Human Ecology Review, Volume 25, Number 1, 2019, published by ANU Press, The Australian National University, Canberra, Australia. doi.org/10.22459/HER.25.01.2019.01 